\title{
Forage Utilization Cost Differentials in a Ranch Operation: A Case Study
}

L. ALLEN TORELL, E. BRUCE GODFREY, AND DARWIN B. NIELSEN

\begin{abstract}
The total cost (fee and non-fee) of grazing BLM, FS, and private deeded rangeland was estimated by partial budgeting procedures from records kept by the Saval Ranch, a northeastern Nevada cow-calf operation. Private rangeland was estimated to be the most expensive forage source at $\mathbf{\$ 2 4 . 9 9}$ per AUM. The total cost of grazing BLM land was estimated to be $\$ 8.07$ per AUM and FS was estimated to cost $\$ \mathbf{9 . 0 8}$ per AUM.
\end{abstract}

The use of America's federally administered rangelands has been associated with controversy for more then a century. One of the issues that has a long history involves the fees charged operators whose livestock are permitted to graze these lands. Numerous authors have discussed this issue (e.g., Nielsen and Workman 1971, Bergland and Andrus 1977, Roberts 1963, Roberts 1967, Nielsen 1982, Foss 1959, Dutton 1953, Gardner 1962, Kearl 1966, Kelso 1947) but much confusion concerning this issue continues today as evidenced by the studies currently being conducted by the Forest Service and Bureau of Land Management as required by the Public Rangeland Improvement Act (PRIA) of 1978. In fact, few issues associated with the use of federally administered lands has received as much attention in the literature. At the heart of this controversy is the general misunderstanding concerning grazing fees and the total costs of grazing public as well a privately owned lands.

Authors are assistant professor, New Mexico State University, Department of Agricultural Economics and Agricultural Business, Las Cruces (at the time of this research a half-time research associate at the University of Nevada, Department of Range, Wildlife and Forestry, Reno, while concurrently working on an advanced degree at Utah State University); associate professor, Utah State University, Department of Economics, Logan; professor, Utah State University, Department of Economics, Logan.

This publication is: Utah Agricultural Experiment Station Journal paper no. 3069 and contribution number 6 of the Saval Ranch Research and Evaluation Project. Bureau of Land Management; Agricultural Research Service; Saval Ranch; College of Agriculture, University of Nevada-Reno; Forest Service, and Soil Conservation Service cooperating.

Manuscript accepted 28 May 1985.
All users of public lands must incur 2 types of costs-fee and non-fee costs. For example, a hunter incurs travel costs (non-fee costs) and may also have to pay an access fee. Similar costs must also be borne by ranchers whose livestock graze public or private lands. Any differences between the total costs (fee and non-fee costs) of grazing 2 different but comparable parcels of land means that economic rents accrue to the parcel with the smallest total cost (see Gardner 1962, Roberts 1963, or Brokken and McCarl 1984).

Numerous studies (e.g., Nielsen and Workman 1971, Gardner 1962, Fowler and Gray 1980) have estimated the "permit value" due to cost differentials between grazing federal and private rangelands. Other studies have surveyed ranchers in an attempt to directly estimate the cost differential between public and private forage sources (e.g., Obermiller and Lambert 1984). No studies have attempted to estimate what differences in cost, if any, exist among the various types of land used by a particular ranching operation.

This case study estimates the costs of using Bureau of Land Management (BLM), Forest Service (FS), and deeded rangeland for a ranch in northeastern Nevada. The unique data from the Saval Ranch for 1982 can not be directly applied to other ranch operations. Furthermore, these costs would be expected to vary overtime. The partial-budgeting procedure outlined, however, can and should be used to estimate the costs of using any site grazed by domestic livestock. The partial-budgeting enterprise analysis described below is needed to make sound economic decisions about a particular site.

\section{Study Area}

The Saval Ranch is located approximately $72 \mathrm{~km}(45 \mathrm{mi})$ north of Elko, Nev. (Fig. 1). The ranch operation includes approximately 19,881 ha. (49,105 acres), including lands owned and managed privately ( 3,060 ha; 7,557 acres $)$, by BLM ( 10,489 ha; 25,908 acres $)$ 


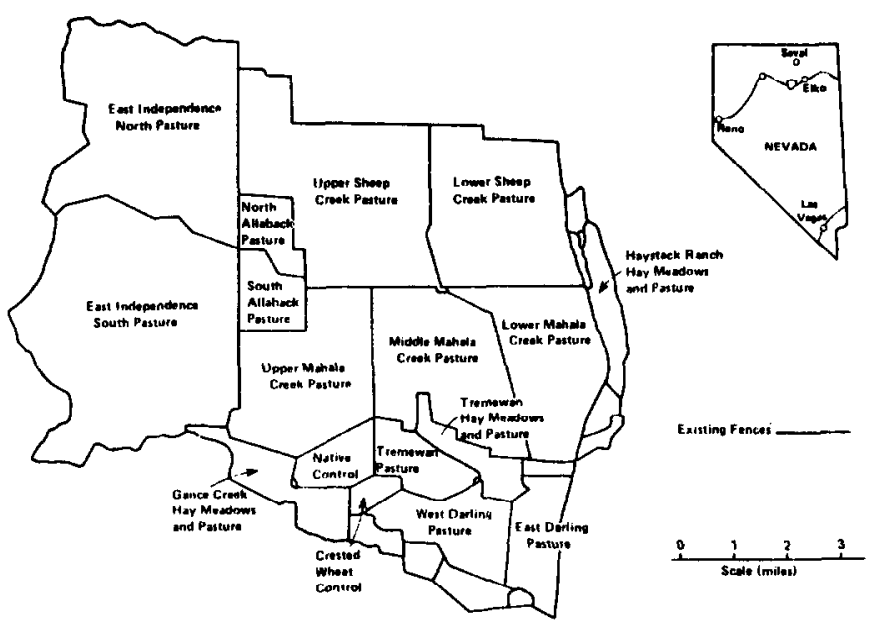

Fig. 1. Location of study area and general layout of the Saval grazing allotment.

and by FS (6,332 ha; 15,640 acres). Native rangeland pastures on BLM lands are fenced into parcels of about 1,620 ha (4,000 acres) (Fig. 1). The "Darling Seeding" crested wheatgrass pastures, which are managed by BLM, are somewhat smaller with an average of 644 ha (1,590 acres) per pasture. FS pastures are larger with 3,692 ha $(9,120$ acres) in the South Independence pasture and 2,640 ha (6,520 acres) in the North Independence pasture.

Elevation of the ranch varies from approximately $1,524 \mathrm{~m}(6,000$ $\mathrm{ft})$ at the Haystack Ranch to nearly $2,438 \mathrm{~m}(8,000 \mathrm{ft})$ on the FS pastures. BLM pastures are on gently sloping alluvial fans located at the base of the Independence Mountains. In contrast, FS pastures are in steep, mountainous terrain. Annual precipitation on the ranch ranges from approximately $3.5 \mathrm{~cm}$ ( 9 inches) at lower elevations to approximately $8.3 \mathrm{~cm}$. (21 inches) at high mountain elevations.

\section{Methods}

The cost of grazing rangeland may be divided into 2 general categories-variable and fixed. "/ariable costs (e.g., salt, labor, supplies) were determined from the ranch's expense and labor records. Fixed costs (e.g., depreciation, interest on investment) were estimated based upon the curren : market value of deeded land and Federal grazing permits.

To estimate the cost of grazing range forage requires that each source of forage be treated as a separate distinct enterprise. That is, total ranch expenses must be divided to allocate ranch expenses to the appropriate activity based on the allocation of labor and material inputs to various production activities. This information was obtained when Saval Ranch employees recorded how much labor each task required. This procedure was followed throughout the grazing season. The ranch manager also estimated labor requirements for the winter feeding period. For simplicity, ranch activities were grouped into the 11 general categories shown in Table 1.

Obviously, the allocation of some ranch expenses may result in some overlap of expense categories. To avoid double-counting, these "joint costs" were allocated to the expense category or categories for which most of the expense was incurred. For example, tractors were primarily used for hay production and winter feeding although they may occasionally be used to maintain fences, cattle

Hertz only compiles per mile driving costs - including insurance, licenses, fees, taxes, loan interest, maintenance, repairs, gasoline, oil and other service station charges, and depreciation-for cars. Trucks are not included. Thus, it was assumed that the per mile cost would be similar between a full-size car is reported by Hertz, and pickup trucks as used on the ranch.
Table 1. Ranch activities performed under each general labor activity designation.
Winter Feeding

Ranch Maintenance

Haying

Irrigating

Working Cattle

Moving Cattle

Range Improvement Maintenance

Summer Care of Cattle

Ranch Management

Miscellaneous
Winter Care of Cattle
Checking and doctoring cattle during the winter and spring months. Calving during the spring.

Feeding cattle hay during the winter months.

Repair of buildings, corrals, roads, and vehicles. Excludes range improvement maintenance and repair of haying equipment.

Putting up grass hay for winter feeding. Includes repair of haying equipment.

Flood irrigation of meadowland. Includes ditch repair and construction.

Branding, vaccinating, weaning, and marketing of cattle.

Herding cattle between allotments. Excludes herding while on a particular pasture.

Maintenance of fences, cattle guards, and other range improvements on both Federal and private lands.

Herding cattle for better distribution on the pasture, salting, and checking cattle on range. Includes travel time to and from the pasture.

Management, bookkeeping, and office work.

Shoeing horses, going to town, and other odd jobs. guards, and other range improvements. In this case, tractor expenses were allocated only to hay production and hay feeding.

Labor expenses were estimated by multiplying the number of hours per labor category times $\$ 5.37$ per hour - the average hourly ranch expense for labor, room, and board. Other cash costs for salt, fencing materials, and other inputs were recorded by the Saval Ranch manager. Vehicle mileage to and from allotments and pastures was estimated from topographic maps of the ranch. The number of trips to allotments was estimated from labor data. Trip mileage was then multiplied by $\$ .34$ per $\mathrm{km}$. ( $\$ 0.55$ per mi.), the estimated average cost, including depreciation, of owning and operating a full-size pickup truck during 1982 (Hertz 1983).1

Private range improvement depreciation and interest on private land investment also reflect "joint expenses." It was not possible to exactly allocate these expense categories between hay AUMs ${ }^{2}$ and private range forage AUMs. Depreciation and interest expenses were allocated between hay production and private range forage production according to the proportion of hay and range forage AUMs produced on private rangeland and meadows (as hay aftermath). These depreciation and interest costs were not, however, used to determine the cost of harvesting forages.

Estimated range improvement depreciation costs were based on initial improvement investment using the straight-line method. Vehicle depreciation was included in the $\$ .34$ per $\mathrm{km}$. charge discussed above.

It was assumed that the Saval Ranch would accept a $10 \%$ return on the current market value of all land and range improvement investments. This represents an "opportunity" cost for funds invested in forage resources. Best estimates of current market value of various private lands on the Saval Ranch are $\$ 1,500 /$ ha $(\$ 600 / a-$ cre) for native meadows, $\$ 187.50 /$ ha. ( $\$ 75 /$ ac.) for native rangeland, and $\$ 250 /$ ha $(\$ 100 /$ acre) for crested wheatgrass (personal communication, July 25, 1983, A. Steninger, Western Ranch Service, Elko, Nev.). Federal grazing allotments in Elko county have a

${ }^{2}$ An animal unit month (AUM) is considered to be the amount of feed or forage required by one mature cow with calf (or the equivalent) for one month. 
current market value of between $\$ 30$ and $\$ 35$ per AUM. A midrange value of $\$ 32.50$ per AUM was assumed in this study.

Forage use during the 1982 grazing season was estimated from BLM and FS grazing records, and actual use records kept by the ranch.

\section{Labor Input}

The total annual labor input into the ranch operation was 12,859 hours during 1982. Of this total, $20.6 \%$ (2,646 hours) were for harvesting range forage. The largest portion of this time $(1,429$ hours) involved moving cattle to comply with BLM and FS grazing requirements. An additional 613 hours was spent maintaining range improvements, and 604 hours were required to care for cattle that were on rangelands. These 3 labor activities are highlighted in Figure 2. These activities result in labor costs that are not directly associated with livestock production but rather is a cost of harvesting range forage (e.g., getting the livestock to the pasture and maintaining improvements).

\section{Forage Use}

The Saval Ranch did not maintain a constant cow herd during 1982. Herd size on the Saval Ranch declined during the year from a high of 1,310 head (including first-calf-heifers) on 31 March 1982, to 713 head on 1 January 1983. The reason for this reduction was the diagnosis of a discasc problem that resulted in the sale open and late calving cows. Since these cows were sold after the grazing period (start of the winter feeding), this herd reduction did not affect the grazing costs reported below.

Annual forage use during the 1982 grazing season was estimated to be 9,410 Animal Unit Months (AUMs). Cattle were turned into the Lower Mahala Creek allotment the first of April ${ }^{3}$, then onto the

${ }^{3}$ Cattle were also fed during this time. Turn-out was allowed to provide protection from wind during calving. For a "normal" year, early turn-out is about April 15 onto crested wheatgrass pastures.

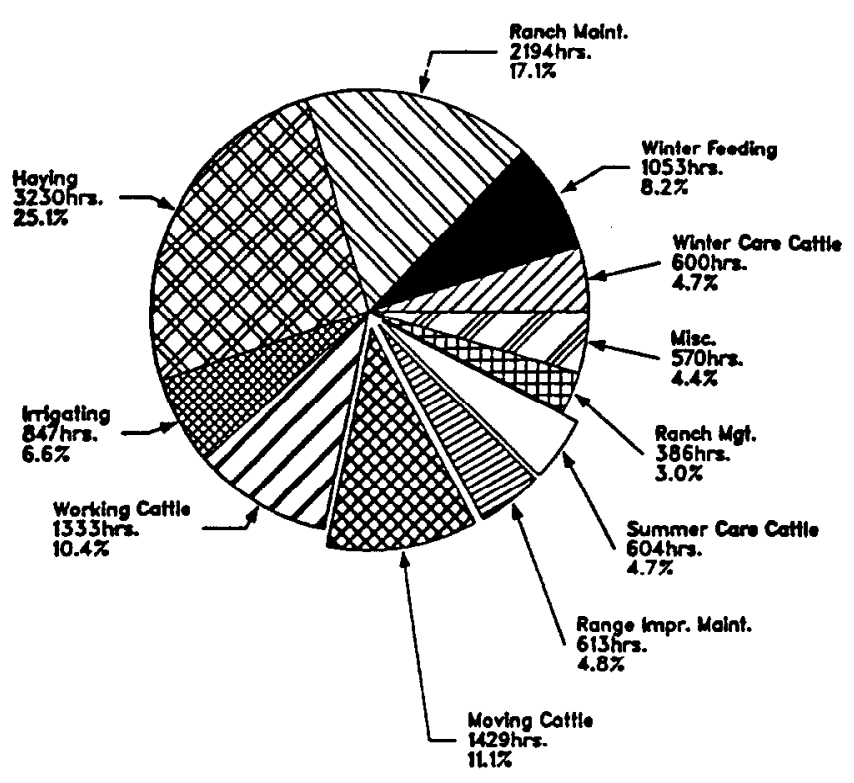

Fig. 2. Ranch labor input by general labor activity.

"Darling" crested wheatgrass seeding, to higher-elevation native BLM range near the end of May, FS pastures the end of June, and back to privately owned fields and pastures during the fall (Fig. 3). Approximately 200 head of cows remained on private land throughout the summer.

During the 8-month grazing season, the Saval Ranch depended upon federal rangeland for $69 \%$ of livestock forage requirements. This included 658 AUMs of forage owned by the ranch but man-

Table 2. Livestock moving costs.

\begin{tabular}{|c|c|c|c|c|c|c|c|c|}
\hline \multirow[b]{2}{*}{$\begin{array}{l}\text { Land } \\
\text { Type } \\
\end{array}$} & \multirow[b]{2}{*}{$\begin{array}{c}\text { Total Herding } \\
\text { Time } \\
\text { (Hours) }^{1}\end{array}$} & & & \multirow[b]{2}{*}{$\begin{array}{c}\text { Total AUMs } \\
\text { Harvested } \\
\text { (AUMs) }\end{array}$} & \multirow[b]{2}{*}{$\begin{array}{c}\text { Labor Cost } \\
\text { at } \$ 5.37 / \mathrm{hr} \text {. } \\
(\$ / A U M)\end{array}$} & \multicolumn{2}{|c|}{-Per AUM Expense-...- } & \multirow[b]{2}{*}{$\begin{array}{c}\text { Total } \\
\text { Cost } \\
\text { (\$/AUM) }\end{array}$} \\
\hline & & (Kilomet & $\begin{array}{l}\text { ge } \\
/ \text { (Miles) }\end{array}$ & & & $\begin{array}{c}\text { Travel Cost } \\
\text { at } \$ .34 / \text { kilometer } \\
\text { (\$/AUM) }\end{array}$ & $\begin{array}{c}\text { Horse } \\
\text { Expense } \\
(\$ / A U M)\end{array}$ & \\
\hline Private & 331 & 180 & $(112)$ & 2,956 & .60 & .02 & .20 & .82 \\
\hline BLM & 485 & 1,031 & (641) & 2,954 & .88 & .12 & .20 & 1.20 \\
\hline FS & 613 & 1,434 & (891) & 3,500 & .94 & .14 & .20 & 1.28 \\
\hline
\end{tabular}

IThe 311 hours spent in moving cattle from Upper Sheep/Mahala BLM allotments to the USFS South independence allotment (Fig. 3) was equally split between BLM and USFS forage sources.

Table 3. Range improvement maintenance costs.

\begin{tabular}{|c|c|c|c|c|c|c|c|}
\hline \multirow[b]{2}{*}{$\begin{array}{l}\text { Land } \\
\text { Type }\end{array}$} & \multirow[b]{2}{*}{$\begin{array}{c}\text { Total } \\
\text { Maintenance } \\
\text { Time (Hours) }\end{array}$} & & \multirow[b]{2}{*}{$\begin{array}{c}\text { Total AUMs } \\
\text { Harvested } \\
\text { (AUMs) }\end{array}$} & \multicolumn{4}{|c|}{ Per AUM Expense-- } \\
\hline & & $\begin{array}{c}\text { Mileage } \\
\text { (Kilometers)/(Miles) }\end{array}$ & & $\begin{array}{c}\text { Labor Cost } \\
\text { at } \$ 5.37 / \mathrm{hr} . \\
(\$ / \mathrm{AUM})\end{array}$ & $\begin{array}{l}\text { Travel Cost } \\
\text { at \$34/Kilometers } \\
\text { (\$AUM) }\end{array}$ & $\begin{array}{l}\text { Fencing } \\
\text { Materials } \\
\text { (\$AUM) }\end{array}$ & $\begin{array}{c}\text { Total } \\
\text { Cost } \\
\text { (\$/AUM) }\end{array}$ \\
\hline Private & 444 & (456) & 2,956 & .81 & .08 & .22 & 1.11 \\
\hline BLM & 60 & (219) & 2,954 & .11 & .04 & .03 & .18 \\
\hline FS & 109 & $(392)$ & 3,500 & .17 & .06 & .05 & .28 \\
\hline
\end{tabular}

Table 4. Cost of caring for cattle while on range.

\begin{tabular}{|c|c|c|c|c|c|c|c|c|}
\hline \multirow[b]{2}{*}{$\begin{array}{l}\text { Land } \\
\text { Type }\end{array}$} & \multirow[b]{2}{*}{$\begin{array}{c}\text { Total } \\
\text { Time } \\
\text { Time (Hours) }\end{array}$} & & & \multirow[b]{2}{*}{$\begin{array}{l}\text { Total AUMs } \\
\text { Harvested } \\
\text { (AUMs) }\end{array}$} & \multirow[b]{2}{*}{$\begin{array}{l}\text { Labor Cost } \\
\text { at } \$ 5.37 / \mathrm{hr} . \\
(\$ / A U M)\end{array}$} & \multicolumn{2}{|c|}{-Per AUM Expense-_-_- } & \multirow[b]{2}{*}{$\begin{array}{l}\text { Total } \\
\text { Cost } \\
\text { (\$/AUM) }\end{array}$} \\
\hline & & (Kilomete & $\begin{array}{l}\text { age } \\
\text { s)/(Miles) }\end{array}$ & & & $\begin{array}{l}\text { Travel Cost } \\
\text { at \$34/Kilometers } \\
\text { (\$AUM) }\end{array}$ & $\begin{array}{c}\text { Salt } \\
\text { (SAUM) }\end{array}$ & \\
\hline Private & 37 & 269 & $(167)$ & 2,956 & .07 & .03 & .09 & .18 \\
\hline BLM & 62 & 592 & $(368)$ & 2,954 & .11 & .07 & .09 & .27 \\
\hline FS & 505 & 2,471 & $(1,536)$ & 3,500 & .77 & .24 & .09 & 1.10 \\
\hline
\end{tabular}




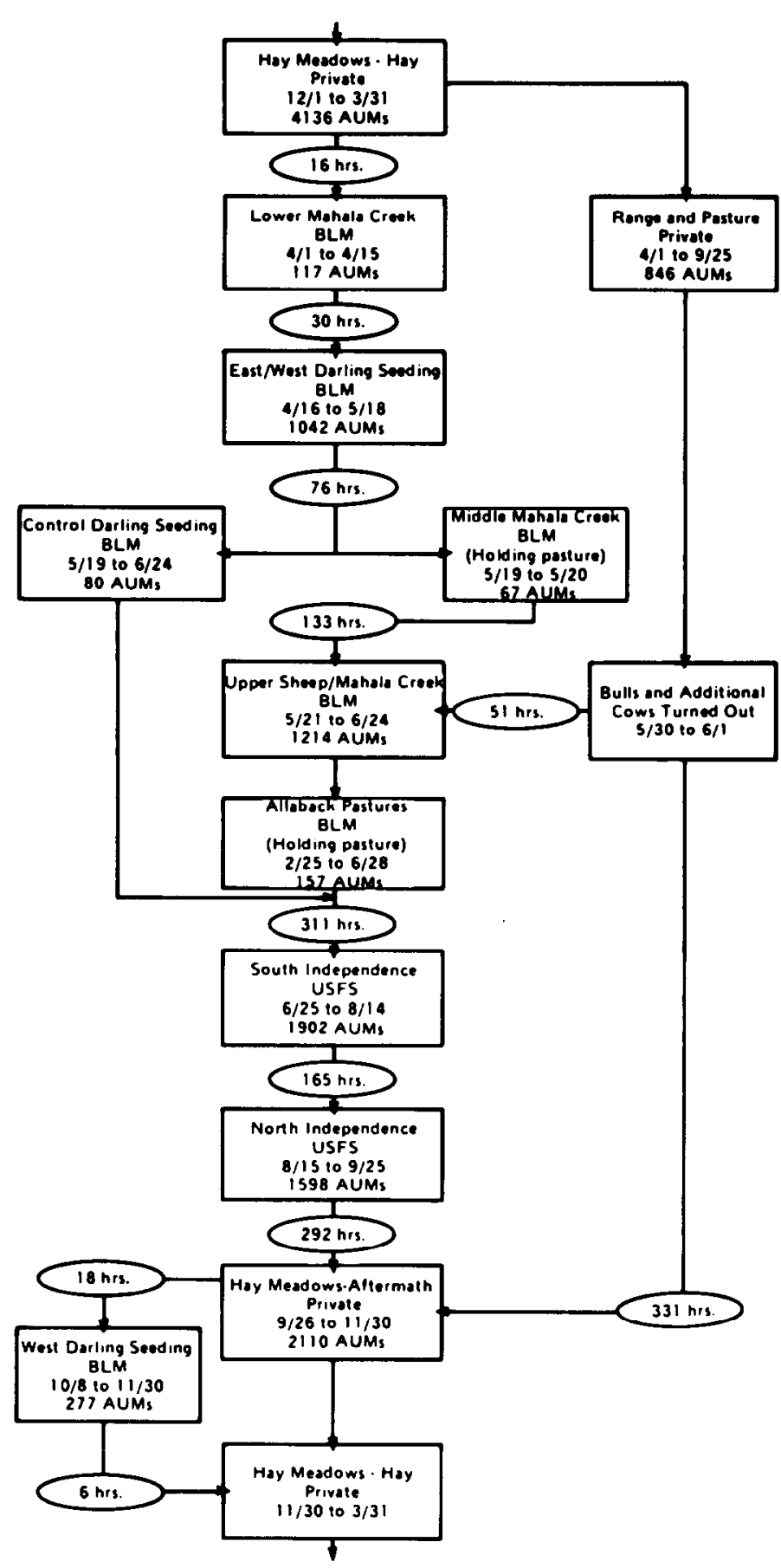

Fig. 3. Forage use during the 1982 grazing season and herding time between pastures.

aged by the BLM and FS under exchange of use agreements.

\section{Specific Forage Utilization Costs Moving Cattle}

A total of 1,429 hours were spent moving cattle among allotments and pastures (Fig. 2). Table 2 shows that the largest amount of time (485 hours) was involved in moving of cattle to, from and between BLM pastures. A smaller amount of time was spent moving cattle onto/ off and between FS pastures ( 613 hours) and private fields and pastures ( 331 hours). Labor costs accounted for approximately $73 \%$ of herding cost for all 3 forage resourcesprivate, BLM and FS.

Depreciation of 15 horses and a horse trailer used to haul these horses added an additional $\$ .20$ per AUM to the herding expense. Total average herding expense per AUM was estimated to be $\$ .82$ for private deeded rangeland, $\$ 1.20$ for BLM lands, and $\$ 1.28$ for FS lands.

There was a wide range in the herding costs for various BLM pastures. The herding expense for BLM pastures close to hay meadows (Darling seeding and Lower/Middle Mahla allotments) averaged only $\$ .76$ per AUM while herding expenses for BLM allotments farther from the ranch headquarters (Upper Sheep and Upper Mahala allotments) averaged \$1.70 per AUM. This difference in cost primarily reflects differences in range productivity (ha/AUM), distance from the ranch headquarters, allotment size, and terrain.

\section{Maintaining Range Improvements}

Labor required to maintain range improvements amounted to 613 hours (Fig. 2). This included primarily the maintenance of fences and cattle guards because the Saval Ranch had no significant investment in water developments. Livestock primarily obtained water from creeks and streams located on allotments.

According to the Saval Ranch manager, relatively little labor and material was required to maintain range improvements during 1982. More maintenance will be required in the future to repair fences that are considered to be in a state of disrepair. Low beef prices and high interest rates did not make these investments possible during 1982. Therefore, the estimated maintenance costs per AUM (\$1.11 for private, \$.18 for BLM, and \$.28 for FS) should be considered to be minimal.

Approximately $72 \%$ of the labor input involved in range improvement maintenance was on private land. A total of $\mathbf{4 4 4}$ hours were spent fixing fences on private land (Table 3). Most of this time (363 hours) was spent maintaining fences around the hay meadows and stack yards to allow cattle to graze aftermath from hay meadows during the fall.

\section{Care of Cattle on Range}

A total of 604 hours were spent tending cattle on range. Most of this time ( 505 hours or $84 \%$ of the time) occurred during the period when cattle were on lands administered by the FS. A trip to check cattle on FS lands generally required a full day of work as a consequence of the steep topography and the rough roads that had to be traversed.

A large part of the 505 hours (Table 4) spent caring for cattle on FS lands involved herding. Cattle tended to congregate near sources of water and had to be moved to prevent overgrazing in riparian zones and to force grazing in other areas which would not have been grazed if extensive herding had not occurred.

BLM and private rangelands used by cattle on the Saval Ranch are relatively flat and require very little herding. As a result, much less time was spent moving, checking, and providing salt for cattle using private ( 37 hours) and BLM ( 62 hours) lands.

The relatively high herding costs required on the FS allotments used by Saval Ranch animals mean the cost of caring for cattle on FS land is nearly 4 times greater than on BLM land and over 6 times greater than for private land. Estimated costs of caring for cattle per AUM are \$.18 for private land, \$.27 on BLM land, and $\$ 1.10$ on FS land (Table 4).

\section{Lost Animals}

The Saval Ranch averages an estimated $3 \%$ annual death loss for all livestock classes. About half of the deaths occur during the winter. Death losses are similar for each type of land (i.e., private, BLM, FS) used by Saval Ranch cattle. Poisonous plants are not a problem on any of the pastures.

Death loss during 1982 was estimated to be worth $\$ 12,341$. Half of the deaths occurred during the period when cattle were using rangelands resulting in an estimated cost of \$1.31 per AUM. 


\section{Veterinary and Medicine}

The ranch spent $\$ 2,793$ for veterinary services and medicine during 1982. Most of this expense was for vaccines and the treatment of calf scours. Cattle using rangelands required little medical attention. As a result, veterinary and medicine expenses during this period were considered as "livestock costs" and not a cost of grazing range forage.

\section{Development Depreciation}

Except for private rangeland and meadows, the Saval Ranch made few private investments for range improvements. The BLM and FS have, however, made substantial investments in range improvements on the Saval Ranch, more than on many other ranches. The estimated value of improvements implemented by federal agencies during 1981,1982 , and 1983 are $\$ 149,381$ (Torell et al. 1985). These investments add nothing to the cost of range forage from the perspective of the ranch except for improvement maintenance.

Approximately $51 \mathrm{~km}(32 \mathrm{mi})$ of fence on the ranch enclose hay meadows, private pastures, and rangeland. Assuming an initial investment of $\$ 808$ per $\mathrm{km}(\$ 1,300$ per $\mathrm{mi}), 20$ years of life, and no salvage value, the annual depreciation cost for the $51 \mathrm{~km}$ of fence is estimated to be $\$ 2,080$ or an average depreciation cost of \$.29/AUM.

\section{Interest on Investment}

The ranch utilizes approximately 691 ha $(1,708$ acres) of privately owned meadowland, 406 ha ( 1,003 acres) of private crested

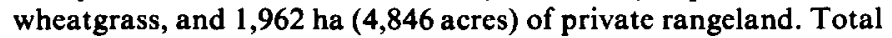
investment in private forage sources is estimated to be $\$ 1,488,855$. This represents a weighted average investment of approximately \$210 per private AUM. Interest costs on this investment are \$21 per AUM if an interest rate of $10 \%$ is assumed.

Estimated interest on the $51 \mathrm{~km}$ of privately owned and maintained fencing is estimated to be $\$ .29$ per AUM while estimated interest on investment in federal allotments is $\$ 3.25$ per AUM.

Interest on investment and depreciation are "non-cash" costs, not "out-of-pocket" expenses, that many ranchers tend to ignore, at least in the short run. Failure to consider these "non-cash" costs greatly reduces the cost of grazing range forage.

\section{Forage Cost Summary}

If the "fixed" costs of forage use are not included, private deeded forage is the least expensive source of forage at \$3.42 per AUMless than federal forage by about the amount of the federal grazing fee (Table 5). When "fixed" costs are included (which they must be in the long run) private deeded forage is the most expensive source of forage (nearly $\$ 25$ per AUM) because interest on investment is $85 \%$ of this cost. While the cost of forage from this source appears to be very high for livestock grazing, forage from this land is essential to feed cattle year-round and it is necessary as "base property" to qualify for federal grazing permits. Furthermore, expensive hay harvested from private lands must be fed during the winter. Generally, western ranches must maintain at least some deeded property to utilize other cheaper sources of forage. In addition, few restrictions exist that limit the use of private lands. Landowners generally have the freedom to use, exclude, and transfer (sell) deeded property and also benefit from increases in property values.

The major advantages of grazing private land is the absence of regulations governing the use of these lands, including restrictions on season of use and stocking rates. Proposed changes in federal lands policy, which among other things could alter the season of use and reduce stocking rates on federal lands, could further enhance the advantage(s) attributable to private land ownership. The direct costs of complying with federal land policies (e.g., herding cattle out of riparian areas, extra herding to remove cattle from an allotment, seasonal use requirements) are included in the total cost figures presented above. Indirect costs, such as time required
Table 5. Forage cost summary.

\begin{tabular}{|c|c|c|c|c|}
\hline Expense Item & $\begin{array}{l}\text { Private } \\
\text { Deeded } \\
\text { (\$/AUM) }\end{array}$ & $\begin{array}{c}\text { BLM } \\
\text { (\$/AUM) }\end{array}$ & $\underset{(\$ / A U M)}{\text { FS }}$ & $\begin{array}{c}\text { Combined } \\
\text { Federal } \\
\text { (\$/AUM) }\end{array}$ \\
\hline \multicolumn{5}{|l|}{ Variable Costs ${ }^{1}$} \\
\hline Moving Cattle & .82 & 1.20 & 1.28 & 1.24 \\
\hline Range Improvement & & & & \\
\hline Maintenance & 1.11 & .18 & .28 & .23 \\
\hline \multicolumn{5}{|l|}{ Care of Cattle on } \\
\hline Range & .18 & .27 & 1.10 & .72 \\
\hline Lost Animals & 1.31 & 1.31 & 1.31 & 1.31 \\
\hline Grazing Fee & - & 1.86 & 1.86 & 1.86 \\
\hline Subtotal & 3.42 & 4.82 & 5.83 & 5.36 \\
\hline \multicolumn{5}{|l|}{ Fixed Costs } \\
\hline \multicolumn{5}{|l|}{ Development } \\
\hline Depreciation & .29 & .00 & .00 & .00 \\
\hline \multicolumn{5}{|l|}{ Interest on } \\
\hline Investment & $21.28^{2}$ & 3.25 & 3.25 & 3.25 \\
\hline Subtotal & 21.57 & 3.25 & 3.25 & 3.25 \\
\hline Total & $\$ 24.99$ & $\$ 8.07$ & $\$ 9.08$ & $\$ 8.61$ \\
\hline
\end{tabular}

"Depreciation and "opportunity cost" charges on vehicles, which are "fixed" expenses, have been included as variable costs for simplicity. This results in a slight descrpancy between "variable" and "fixed" expense classifications.

2This represents a weighted average based on 4136 AUM's from fed hay, 846 AUM's from private range and pasture and $2210 \mathrm{AUM}$ 's from grazing the aftermath on hay meadows.

to negotiate with federal agency personnel, are not included in the above cost estimates.

Forage from BLM lands appears to be the least expensive source of forage for the Saval Ranch ( $\$ 8.07$ per AUM) if the 1982 grazing fee of $\$ 1.86$ per AUM is included. Approximately $52 \%$ of BLM non-fee cost is for interest on the ranch's investment in the BLM grazing permit.

The estimated non-fee cost of FS forage is more than $\$ 1.00$ per AUM higher than it is for BLM forage. Most of this difference is the result of additional care needed for cattle using FS lands including salting, checking cattle, and herding cattle for better distribution. Total non-fee costs for forage obtained from FS lands is estimated to be $\$ 7.22$ per AUM. The total cost of using FS lands is $\$ 9.08$ per AUM when the 1982 grazing fee is included. The weighted average cost of using federal lands by the Saval Ranch is estimated to be $\$ 8.61$ per AUM.

\section{Discussion}

The Saval Ranch headquarters are located closer to range forage than many other ranches. Since the headquarters are located adjacent to federal and private pastures, cattle do not need to be trucked except when sold. The ranch has very minimal private investments in range improvements on federal rangeland. As a result, this ranch's cost of grazing rangelands is probably less than those for other ranches who must truck and move cattle substantial distances, and/or have substantial investments in water developments, fencing, and other range improvements.

Results of this study suggest that a ranch incurs different costs when cattle graze different parcels of land. This suggests that the net returns obtained from grazing these differing parcels will also differ even if the same gross return is obtained from each area. As a result, average costs probably do not reflect the net value that results from grazing livestock in a particular area. Furthermore, the non-fee costs will commonly exceed the fees that are charged for using an area of rangeland.

The cost differences shown in this study can not be used as the basis for establishing a fee for the use of public or private lands because these costs do not reflect the value of forage. The value of grazing any area should be based on the performance of animals grazing these areas after the fee and non-fee costs of obtaining this forage have been subtracted. Fee and non-fee costs, such as those 
estimated above, would have to be subtracted from the revenues obtained from using an area before the value of forage obtained from any source of forage (e.g., BLM, FS, private) could be estimated.

The higher variable costs incurred when grazing public lands suggest that lease rates for use of private lands may be higher than those for using public lands. However, these higher fees could only be obtained if: (a) both types of lands yielded equal returns and (b) the opportunity costs of investments for private lands were ignored (or reduced significantly).

Even though grazing range forage is relatively inexpensive on the Saval, non-fee costs are still substantial. Variable costs for both BLM and FS lands are at least 1.5 times the grazing fee. Grazing fees comprise about $22 \%$ of this ranch's total estimated cost of grazing federal rangelands during 1982 . This suggests that the "non-fee" costs of grazing federal rangeland must also be considered whenever changes in federal land grazing and pricing policies are proposed.

\section{Literature Cited}

Berglund, B., and C.. Andrus. 1977. Study of fees for grazing livestock on federal land. A report from the secretaries of agriculture and Interior. U.S. Government Printing office. Washington D.C.

Brokken, R.F., and B.A. McCarl. 1984. A theoretical evaluation of fee systems for private grazing on federal lands. A report for the USDAForest Service and USDI-Bureau of Land Management by USDAEconomics Research Service.

Dutton, W.L. 1953. History of Forest Service grazing fees. J. Range Management. 6:393-398.
Foss, P.O. 1959. The determination of grazing fees on federally owned rangelands. J. Farm Econ. 41:535-547.

Fowler, J.M., and J.R. Gray. 1980. Market values of Federal grazing permits in New Mexico. New Mexico Coop. Ext. Serv. Range Impr. Task Force Rep. 2

Gardner, B.D. 1962. Transfer restrictions and misallocation in grazing public range. J. Farm Econ. 44:50-63.

Hertz Corporation. 1983. Press information regarding driving costs. Public Affairs Dep. New York, New York.

Kearl, W.G. 1966. Fees and charges as tools of public policy-a discussion. J. Range Management. 19:245-247.

Kelso, M.M. 1947. Current issues in federal land management in the western United States. J. Farm Econ. 29:1295-1313.

Nielsen, D.B. 1982. Grazing fees for public lands: What's fair? Utah Science 43:1-5.

Nielsen, D.B., and J.P. Workman. 1971. The importance of renewable grazing resources on Federal lands in the 11 western states. Utah Agr. Exp. Sta. Cir. 155.

Obermiller, F.W., and D.K. Lambert. 1984. Costs incurred by permittees in grazing livestock on public lands in various western states. Oregon State University coop. Extension Services. EM 8283.

Roberts, N.K. 1963. Economic foundations for grazing use fees on public lands. J. Farm Econ. 45:721-731.

Roberts, N.K. 1967. Discovering grazing values. J. Range Management. 20:369-375.

Torell, L.A., E.B. Godfrey, and R.E. Eckert Jr. 1985. Optimal livestock production stratagies on the Saval Ranch. University of Nevada-Reno. Agr. Exp. Sta. Tech. Bull. (TRB) \#1.

Statement of Ownership, Management, and Circulation (Act. of August 12, 1970, Sec. 3685, Title 39, United States Code)

SRM Election Results

The Elections Committee Chairman Don Smith, along with several other Colorado Section members, counted the ballots for new offices on Monday, December 9, 1985, at the Society for Range Management headquarters. Elected officers are:

\section{Second Vice-President-William (Bill) A. Laycock}

\section{Directors (1986-1988) _ Gary Donart and Tommy Welch}

Directors Donart and Welch will replace retiring Directors Currie and Fischbach in February 1986.

Ballots and tally sheets are retained in the Denver office for one year for review. Approximately $28 \%$ of the membership voted.
1. Title of Publication: Journal of Range Management

2. Date of Filing: September 24, 1985

3. Frequency of Issue: Bimonthly

4. Location of Office of Publication: 2760 West Fifth Ave., Denver, Colo. 80204

5. Location of General Business Office: Same

6. Name and Address of: Publisher: Society for Range Management, 2760 West Fifth Ave., Denver, Colo. 80204

Editor: Patricia Smith 2760 West Fifth Ave., Denver, Colo. 80204

Managing Editor: Peter V. Jackson III 2760 West Fifth Ave., Denver, Colo. 80204

7. Owner: Society for Range Management, 2760 West Fifth Ave., Denver, Colo. 80204

8. Known Bondholders, Mortgagees, etc.: None

9. For Completion by Nonprofit Organizations Authorized to Mail at Special Rates: The purpose, function, and nonprofit status of this organization and the exempt status for Federal income tax purposes have not changed during preceding 12 months.

10. Extent and Nature of Circulation

\begin{tabular}{rr} 
Avg. for & \multicolumn{2}{c}{ Actual for } \\
issue nearest \\
12 months & $\begin{array}{c}\text { filing date } \\
6,859\end{array}$ \\
& 6,700 \\
0 & 0 \\
5,914 & 5,868 \\
5,914 & 5,868 \\
20 & 15 \\
5,934 & 5,883 \\
925 & 817 \\
6,859 & 6,700
\end{tabular}

I certify that the statements made by me above are correct and complete.-Peter V. Jackson, Managing Editor. 